\title{
EXPENDITURE FLUCTUATION AND CONSUMPTION LOSS: RURAL SPATIAL POVERTY IN CHINA
}

\author{
Xiang LUO', Jingjing QIN¹, Qing WAN², Gui JIN ${ }^{3 *}$ \\ ${ }^{1}$ School of Public Administration, Central China Normal University, 430079 Wuhan, China \\ ${ }^{2}$ School of Management, Wuhan Institute of Technology, 430205 Wuhan, China \\ ${ }^{3}$ School of Economics and Management, China University of Geosciences, 430074 Wuhan, China
}

Received 25 November 2020; accepted 16 May 2021; first published online 08 September 2021

\begin{abstract}
Poverty is a challenge faced by all countries worldwide. This paper focuses on a factor that has been less well documented: the consumption loss of farmer households caused by the fluctuation of rural public expenditure. Based on large-scale micro household data and climate data, the instrumental variable estimation results show that every $1 \%$ fluctuation of rural public expenditure will lead to a $0.113 \%$ decrease in farm household consumption. In addition, the fluctuation of rural public expenditure is also a main cause of long-term consumption loss of farmer households. Furthermore, it was found that the impact of rural public expenditure fluctuation on consumption loss is of certain spatial heterogeneity. The worse the spatial environment is, the more serious the consumption loss will be. The policy suggestion of this paper is to ensure a stable scale of rural public expenditure through the central transfer payment, so as to improve the ability of local governments to implement counter cyclical public policies, and transform local finance (industrial investment) into public finance (infrastructure and education) to improve the local space environment. Overall, this study reveals the impact of spatial externality on rural poverty from the perspective of public expenditure fluctuation, and at the same time provides empirical evidence for a better evaluation of the relationship between development and poverty and support for rational regional anti-poverty policies.
\end{abstract}

Keywords: expenditure fluctuation, consumption loss, spatial poverty, China.

JEL Classification: E62, I32, O15, R11.

\section{Introduction}

Poverty is a serious challenge faced by all countries worldwide. Effective reduction of poverty has always been a hotspot in academic research and policy governance. In developing countries, poverty mainly occurs in rural areas. Hence, understanding rural poverty is the basis for the governance of poverty in a certain country. Previous studies have suggested that

*Corresponding author. E-mail: jingui@igsnrr.ac.cn

Copyright (c) 2021 The Author(s). Published by Vilnius Gediminas Technical University

This is an Open Access article distributed under the terms of the Creative Commons Attribution License (http://creativecommons. org/licenses/by/4.0/), which permits unrestricted use, distribution, and reproduction in any medium, provided the original author and source are credited. 
poverty reduction is largely determined by economic growth and labor mobility (Dollar \& Kraay, 2002; Besley \& Burgess, 2003; Kraay, 2006). However, due to various externalities such as geography, language, customs and culture, the mobility of labor is often inadequate. As a result, the trickle-down effect of economic growth will not automatically benefit the poor. Therefore, the traditional theory of "when the river rises, the boat floats high" often fails to explain the fact that continuous economic growth is often accompanied by massive persistent poverty in most developing countries (Ravallion, 2001).

Some new research has begun to highlight the important effect of space environment on rural poverty (Jin et al., 2020b; Epprecht et al., 2011; Barbier \& Hochard, 2019). Researchers believe that for families of the same characteristics, those living in areas with a better "space environment" are more likely to get out of poverty eventually, while those living in areas with a poorer "space environment" still cannot get rid of poverty even facing the same economic growth prospect and fall into poverty trap. However, the existing research on spatial poverty does not illustrate how "spatial disadvantage" causes rural poverty, particularly persistent rural poverty. We speculate that understanding the relationship between rural public expenditure fluctuation and consumption growth rate can provide important clues for elucidating the causes of spatial poverty, which has received little research attention in previous literature. In rural areas, due to the lack of formal credit and insurance market, rural public expenditure and informal insurance play important roles in the smoothing of household consumption. This paper attempts to prove that under spatial poverty, the negative impact on farm households is homogeneous, and the role of informal insurance will be weakened (Glauben et al., 2012); once the rural public expenditure is fluctuating, the farm households shocked by risks will first smooth their basic consumption (such as food spending) and then reduce their productive consumption, which will cause consumption loss and persistent poverty.

At the same time, the current characteristics of China's rural poverty also offer an ideal research background for verifying the relationship between expenditure fluctuation and consumption loss. On the one hand, China's rural poverty and economic growth are not spatially synchronized, and the majority of the existing rural poor population are distributed in the "contiguous destitute areas" in the central and western regions (see Figure 1). These areas have harsh natural environments, most of which are deep or rocky mountain areas, alpinecold areas and frequent disaster areas. The adverse natural environment seriously limits the accessibility of the market and the development of formal finance, which largely reduces the poverty reduction effect of economic growth. On the other hand, these "contiguous destitute areas" are usually remote or the habitat areas of minorities with relatively significant intergenerational transmission of poverty (Liu et al., 2017), which weakens the role of informal social capital in resisting exogenous shocks. These facts imply that public expenditure may play a crucial role in reducing spatial poverty (Hidalgo-Hidalgo \& Iturbe-Ormaetxe, 2018). However, there is still a lack of direct empirical evidence about the impact of the characteristics of public expenditure itself (cyclical fluctuations) on rural poverty, and whether these impacts vary with different space environments.

Therefore, we first constructed an extended Ramsey model, which is introduced as the micro basis for examining the impact of rural public expenditure and geographical variables on rural poverty (farmers' utility). The conclusion of the model is that both rural public 

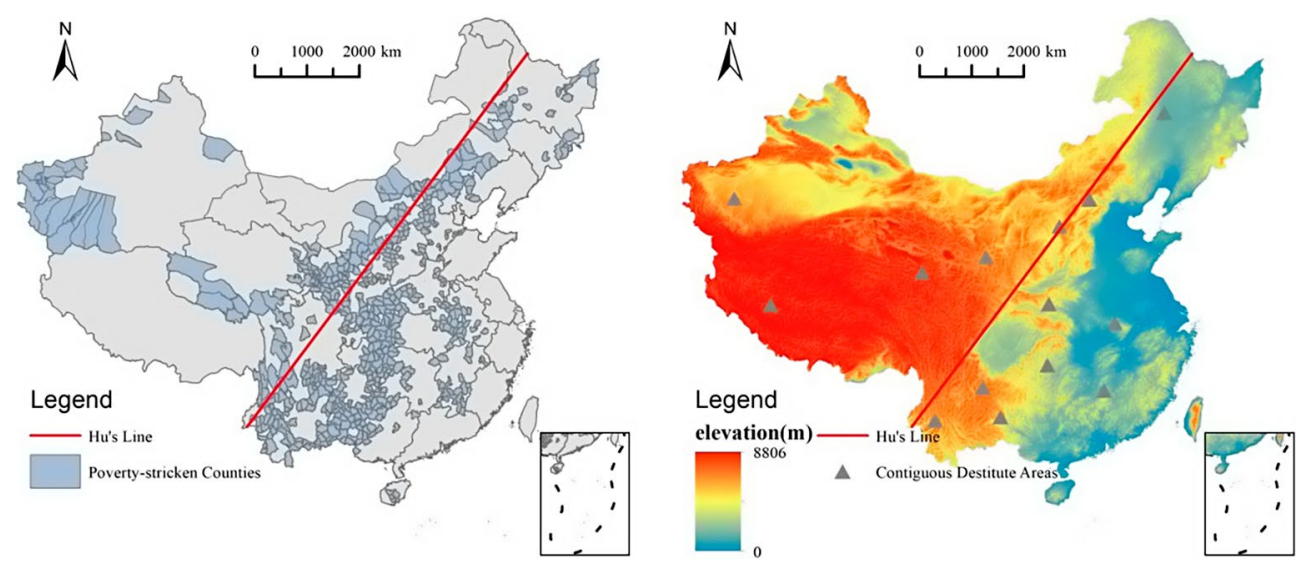

Figure 1. Spatial distribution characteristics of rural poverty in China

expenditure and geographical variables affect the consumption growth rate of farmer households; and since the geographical variables are usually not changeable in short term, rural public expenditure will have a crucial impact on the consumption of farmer households. On this basis, we used large-scale micro farmer data and climate data to empirically examine the relationship between public expenditure fluctuation and consumption growth rate. The results show that the public expenditure fluctuation measured by standard deviations of growth rate has a significant negative impact on the consumption growth rate of farmer households, particularly in areas with worse space environment. Theoretical modeling and regression testing were performed to explain that under adverse geographical conditions and lack of formal market, which is mostly the case in poor rural areas, rural public expenditure fluctuation will "deteriorate" the expectation of farmers, leading to consumption loss and falling of poor farmer households into persistent poverty.

\section{Literature review}

In traditional studies of rural poverty, income and family characteristics were taken as the core factors (World Bank, 1981, 2000a, 2000b; Sen, 1999; Dong et al., 2021). Correspondingly, economic growth is believed to benefit the poor in both income and capability, and thus is considered as the most important factor affecting rural poverty (Dollar \& Kraay, 2002; Besley \& Burgess, 2003; Kraay, 2006). In contrast, the impact of "spatial externalities" on rural poverty is not taken into full account. However, the regional economic development in many countries has clearly demonstrated that there is no synchronous relationship between economic growth and rural poverty reduction. In particular, persistent rural poverty is often found in some areas with high-speed economic growth (Ravallion \& Wodon, 1999; Ravallion, 2001; Jin et al., 2020a; Zhou \& Xiong, 2017; Shujaat \& Usman, 2020).

With the first concern to the global distribution of poverty by the World Bank in the mid-1990s, researchers began to establish links between rural poverty and geographic factors. Based on the Cass-Koopmans-Ramsey Model, Jalan and Ravallion (2002) incorporated geo- 
graphic externality into the model of farmers' consumption growth decisions by introducing the concept of geographic capital. The model concludes that geographic capital will affect the marginal output of household-owned capital. Further, through regressing micro panel data from 1985 to 1990 in four southern provinces (Guangdong, Guangxi, Guizhou, and Yunnan), they found that geographic capital has a significant impact on household consumption growth, so there are geographic poverty traps in rural areas. The concept of the geographic poverty trap has been widely used in subsequent studies. Since geographic capital contains information such as geography, nature, culture, and institution that are related to "space" in empirical research, geographic poverty traps are usually regarded as spatial poverty traps (Alkire et al., 2015). For examples, Bird and Shepherd (2003) identified spatial poverty traps as where geographic capital is low and poverty is high; Daimon (2001) identified "spatial poverty traps" as excessive migration costs and persistent poverty caused by geographic externalities.

Although the aggregated geographical data can explain the persistence of poverty to some extent, they cannot distinguish whether the "divergence" of income and growth is derived from the growth of individual wealth or the geographical externality (Jalan \& Ravallion, 2002). In particular, although the role of geographical externality is taken into account, the regression of geographical factors alone cannot explain why there are deep poverty traps in some areas with better geographical conditions (Bloom et al., 2003; Dao \& Edenhofer, 2018). In fact, in developing countries, a basic consensus on rural poverty is that the poor farmer households are usually vulnerable to large external shocks (Zimmerman \& Carter, 2003; Christiaensen \& Demery, 2007). Especially under synergetic shocks (such as natural disasters), the loss of farmer households' welfare will be persistent (Dercon, 2002). Accordingly, there are usually two choices for poverty-stricken farmer households to resist the random external shocks: one is informal risk sharing (social capital), and the other is formal fiscal assistance (public expenditure).

However, in areas with harsh space environments, the role of social capital and public expenditure in resisting the impacts of external risks will be "weakened". On the one hand, in remote rural areas, the natural, cultural and ethnic barriers make it difficult for the poor population to flow between regions (Jalan \& Ravallion, 1999; Jin et al., 2018), and the social network of the family is usually limited in a small space. In addition, there is a more significant intergenerational transmission of poverty in the farm households of poor areas (Liu et al., 2017; Guo et al., 2020). Therefore, geographical isolation severely reduces the effects of social capital on rural poverty reduction. On the other hand, financial markets are usually absent in most poor rural areas. When the farmer households are faced with negative shocks, informal risk sharing and farmers' own savings can only ensure partial consumption smoothing, which will cause higher "consumption risks" (Dercon \& Christiaensen, 2011). Once the poor households are faced with fluctuating public expenditure, they tend to reduce the investment in production technology and adopt relatively more conservative (low return) production methods, and finally fall into persistent poverty.

Besides, it is difficult to explain the cause of transient poverty simply from the perspective of geographical factors. According to the national sample survey conducted by the Chinese Academy of Social Sciences (CASS) in 2006, if the incidence of poverty is calculated based 
on the standard of $\$ 1$ per capita, the income poverty is higher than the consumption poverty, indicating that a considerable number of poor farmers in China may be in transient poverty. The division of transient poverty and persistent poverty further highlights the importance of public expenditure fluctuations in the research on poverty. Because of the different causes of transient poverty and persistent poverty, public expenditure fluctuation may have different impacts on them. In particular, transient poverty is mainly related to external shocks (Xu et al., 2011), which means that under an unstable scale of fiscal subsidies, the time horizon of the farmers will be shortened, while the "pessimistic" expectation will degenerate their future consumption and lead to transient poverty (Laajaj, 2017). To some extent, this can explain why the poverty-returning rate in poor areas has always been high even in the period of rapid economic growth.

The above literature on rural poverty illustrates that it is the existing risks rather than the capacity of farmers that lead to rural poverty. As an important source of external risks, space environment is receiving increasing attention in the research on rural poverty. The current research on spatial poverty primarily focuses on the role of geographical factors in the growth of household consumption. Although the regression of poverty with geographical variables can confirm the impact of geographical factors on the incidence of rural poverty, it cannot elucidate the exact reasons for spatial poverty. Theoretically, the reason for the households to fall into poverty is their lack of ability to resist the risk shock instead of the risk shock itself. Obviously, to explain spatial poverty only from the perspective of geographical factors is not "complete". In addition, empirical studies of poverty based on geographical regression also cannot provide explicit policy implications. If geography is recognized to have an important impact on rural poverty, it is evident that the geographical environment cannot be changed in a short time, and at the same time there are certain obstacles for the mobility of population. Then, it will be a great challenge to adjust the public policies for better reduction of rural poverty. This is also an important reason why the existing research fails to provide reasonable explanations for transient poverty in most developing countries. For example, Rozelle et al. (2000) believes that China's poverty alleviation policies are mainly for persistent poverty, but have little effect on transient poverty.

We believe that the examination of rural poverty from the perspective of spatial poverty should include "policy environment" besides "geographical environment". In fact, in the latest studies, scholars have begun to notice the impact of specific regional conditions on public policies. In these studies, a conclusion closely related to the topic of this study is that rural public expenditure is pro-cyclical in the underdeveloped areas of developing countries (Combes et al., 2019; Luo et al., 2020). In particular, when facing an unstable scale of public expenditure, in order to smooth their consumption, poor households tend to reduce their productive investment and possibly fall into persistent poverty. It remains to be determined how important is a stable public expenditure policy for decreasing consumption loss (consumption smoothing) so as to reduce poverty. The case of Progresa project in Mexico may provide some important clues. The Prograsa project is a key project implemented by the Mexican government to improve the human capital of poor families. The project is directly targeted at the extremely poor in rural areas and the urban fringe areas, and attempts to alleviate chronic poverty by providing conditional cash transfer (CCT) payment to mothers in 
each poor family. In 2004, the project covered about five million families, 25 million people and spent about $\$ 2.5$ billion, which is equivalent to nearly $0.3 \%$ of Mexicos GDP of the year. The core idea of the Progresa project is to subsidize education to enhance human capital, so as to break the intergenerational transmission of poverty and alleviate inequality (Schultz, 2004). Therefore, the project mainly reduces poverty through two channels: provision of cash transfer payment for children's primary and secondary school enrollment, or subsidies for children's nutrition supplement and health infrastructure.

In terms of policy effect, the Progresa project, in a formal form of risk sharing, effectively reduces the uncertain income risk of poor families and realizes consumption smoothing. On the whole, participation of the family in the program increased the time of children's basic education by more than 0.5 year compared with those who did not participate in the program (Shim, 2014). Furthermore, for those families located in "rich" villages, they not only suffered less from the impact of external risks, but also had a better local social network, which is conducive to the transfer of cash between families so as to achieve a better consumption smoothing, resulting in a higher school enrollment rate in these families (Angelucci et al., 2009).

In fact, the empirical study of the Progresa project in Mexico has implied that the impact of spatial heterogeneity should not be ignored when examining the impact of public policy on poverty governance. Finally, it should be pointed out that Progresa is a CCT project (only the eligible families can get cash assistance), instead of a strict public expenditure policy. Therefore, it is difficult to get the general implications of public governance from a specific project (such as Progresa). Particularly, with some common characteristics of government expenditure behavior in developing countries (such as procyclicality), the research based on the "commonness" of government expenditure behavior (cyclical fluctuation) and household consumption behavior (consumption loss) may be more extrapolative, which is also one of the major contributions of this paper.

Many researchers of development economics agree that the basic premise for the reduction of rural poverty is to achieve a minimum growth rate of per capita consumption (Jalan \& Ravallion, 2002; De Vreyer et al., 2009; Dercon \& Christiaensen, 2011), but in these studies, the "consumption loss" of households is not regarded as the result of the "expenditure fluctuation", which is the main academic contribution of this paper. At the same time, current research does not relate the poverty reduction effect of public policies to space environment, which is also complemented in this study. As a whole, this paper incorporates "policy environment" into "space environment" for the study of poverty, which is a further development of the general theory of spatial poverty. Besides, this paper also examines the "consumption loss" of farmer households from the perspective of public expenditure fluctuation, which is also a complement to the existing explanations. Specifically, from the existing literature on development economics, "consumption loss" is mainly related to incomplete rural credit and insurance markets (Eswaran \& Kotwal, 1990; Rosenzweig \& Binswanger, 1993; Narayan et al., 2000; Dercon, 2002; Zimmerman \& Carter, 2003; Dercon \& Christiaensen, 2011). 


\section{Theoretical framework and econometric model}

\subsection{Theoretical model}

In this section, we examine the production process of farmer households in an incomplete market including geographical externality and fiscal subsidies. In the $t$ period, the output of the household $i$ is defined as $y_{i t}=\left(K_{i t}, G_{i t}\right)$, in which $K_{i t}$ is the augmented capital including human capital and material capital, and $G_{i t}$ is the vector form of geographical capital at the village/community level. Further, because of the imperfect rural financial market, the output of the farm households depends on the accumulation of capital or government subsidies. Accordingly, the intertemporal optimal choice of the households based on Ramsey model under constraints can be expressed as:

$$
\left\{\begin{array}{c}
\max _{\left\{c_{i t}\right\}} \sum_{t=0}^{\infty} u\left(c_{i t}\right) \\
\text { s.t. } K_{i, t+1}=(1-\delta) K_{i t}+F\left(K_{i t}, G_{i t}\right)+g\left(k_{i t}\right)-c_{i t} .
\end{array}\right.
$$

In Formula (1), $\delta$ is the accumulated depreciation coefficient of capital; $c$ is consumption; $g$ is the fiscal subsidy, and the degree of subsidy depends on the accumulated capital of the households (wealth). We then rewrite Formula (1) into the form of Bellman equation:

$\cdots+\beta^{t} u\left[F_{i t}(\cdot)-K_{i, t+1}+(1-\delta) K_{i t}+g_{i t}(\cdot)\right]+\beta^{t+1} u\left[F_{i . t+1}(\cdot)-K_{i, t+2}+(1-\delta) K_{i, t+1}+g_{i, t+1}(\cdot)\right]+\cdots$

After taking the partial derivative of $K_{i, t+1}$, the first order condition for maximizing utility is

$$
\frac{u^{\prime}\left(c_{i t}\right)}{u^{\prime}\left(c_{i, t+1)}\right.}=\beta\left[F_{K}^{\prime}\left(K_{i, t+1}+G_{i, t+1}\right)+g^{\prime}\left(K_{i, t+1}\right)+(1-\delta)\right] .
$$

The utility function is set in the isoelastic form $\left(u_{i t}=\frac{c_{i t}^{1-\delta}}{1-\delta}\right)$, and Formula (4) can be obtained by taking logarithm on both sides of Formula (3) and ignoring the unimportant terms.

$$
\frac{\Delta c_{i}}{c_{i}}=F_{K}^{\prime}\left(K_{i, t+1}+G_{i, t+1}\right)+g^{\prime}\left(K_{i, t+1}\right)-\delta .
$$

The left of Formula (4) is the consumption growth rate of farmer households. Since the accumulated depreciation of capital usually remains constant, it is obvious that the consumption growth rate of the households depends on the accumulated capital, the geographical factors and the scale of public expenditure.

\subsection{Setting of econometric model}

According to the basic conclusion of Formula (4), the econometric model of this paper is set as follows:

$$
\Delta \operatorname{Ln} c_{i j t}=\beta_{0}+\beta_{1} \operatorname{Expfl}_{i t}+\beta_{2} X_{i t}+\beta_{3} Z_{j t}+\alpha_{i}+\gamma_{t}+\varepsilon_{i j t} .
$$

In Formula (5), the subscript $i$ represents the household, $j$ stands for the village/community, and $t$ indicates the period. The explained variable $\Delta \operatorname{Ln} c_{i j t}$ is the consumption growth rate 
per capita of households. In development economics, a basic consensus of poverty reduction is that the consumption growth rate must be kept at a minimum (Jalan \& Ravallion, 2002; Dercon \& Christiaensen, 2011). In addition, empirical research has also shown that people with the lowest consumption growth rate tend to gather in space (De Vreyer et al., 2009). Therefore, we use household consumption growth rate to measure the spatial poverty. The explanatory variable is the fluctuation of rural public expenditure. Specifically, we use the standard deviation of the growth rate of public expenditure within three years as the measurement

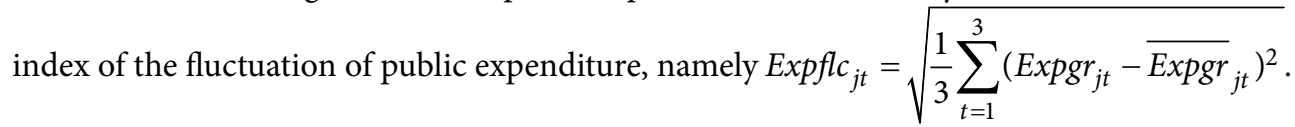
Exgrc $_{j t}$ is the annual growth rate of rural public expenditure, which is measured by the total amount of family subsidies provided by the government. It should be pointed out that the advantage of using growth rate is to eliminate endogenous bias. Generally speaking, a household that can get the government's monetary subsidy is relatively poor. The poorer the household is, the more government subsidies it may obtain, and correspondingly, the marginal propensity to consume is usually lower. The growth rate can more accurately reflect the impact of external shocks; $X_{i t}$ is the control variable at the household level, and $Z_{j t}$ is the control variable at the village/community level; $\alpha_{i}$ is the individual fixed effect; $\gamma_{t}$ is the time fixed effect and $\varepsilon_{i j t}$ is the error term. The core mechanism of Formula (5) is the impact of public expenditure fluctuation on household consumption. As has been repeatedly stressed, the fluctuation of public expenditure will worsen the expectation of the household, resulting in consumption loss. Therefore, we expect that $\beta_{1}$ is significantly negative.

In the household control variable $X_{i t}$, income is the core factor, which directly determines consumption as well as the scale of public expenditure. Besides, the impact of household assets on consumption and public expenditure is also important. On the one hand, the households can use their assets (including physical assets and financial assets) to smooth consumption (Islam \& Maitra, 2012; Ohno, 2015); on the other hand, household assets are also related to the amount of government subsidies. Finally, we also include other important factors proved in existing empirical studies that affect household consumption, such as health, education, age, gender, dialect and social capital owned by the households (Chiswick \& Miller, 1995; Chou et al., 2004; Munshi \& Rosenzweig, 2009; Zou \& Liu, 2010; Segal \& Podoshen, 2013) $)^{1}$. Since the consumption decision of a family is usually made by the household head, we use the health status and education years of the household head to measure the health and education level of the household.

Therefore, the control variables at the household level include: Income $_{i t}$ (income), Assectper $_{i t}$ (asset), familys if $_{\text {(family size), Health }}$ (health status), Party ${ }_{i t}$ (whether the household

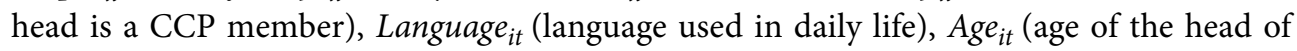
the household), $A g e_{i t}{ }^{2}$ (square of age of the household head), Gender_dum ${ }_{i t}$ (gender dummy variable of the household head), Education (education years of the household head). Finally, it should be noted that political identity serves as an important social network in rural China. For example, if the household head is a CCP member, the household may have certain advantages in employment in the labor market and the probability of getting loans. At the same

\footnotetext{
${ }^{1}$ Since the consumption decision of a family is usually made by the household head, we use the health status and education years of the household head to measure the health and education level of the household.
} 
time, it may also have certain positive effects on the children's educational opportunities and the family's medical status. These are important factors that affect the level of family welfare and poverty. In empirical research, Knight and Yueh (2008) defined party membership as social capital. Therefore, we include Party $_{i t}$ to control the impact of social capital.

Geographical location is a very important factor in the control variable $Z_{j t}$ at the village/community level. On the one hand, geographical location affects the poverty reduction effect of economic growth. For example, the remoteness will reduce private investment, restrain the local demand, and hinder the development of local economy to reduce rural poverty, thus causing damage to the income/consumption growth of farmers (Christiaensen \& Demery, 2007). On the other hand, remoteness also seriously limits the provision of rural public goods (Bird \& Shepherd, 2003). The topography of the village/community location is another important factor. The latest research proves that topographical conditions not only affect the income of farmers, but also influence the scale of public expenditure (Dinkelman \& Schulhofer-Wohl, 2015; Luo et al., 2019). Besides, the impact of customs on rural poverty cannot be ignored (Bebbington, 1999). Especially in minority areas, since "immobility" and "settlement of generations" are normal, the "acquaintance society" will contribute to regional specific language, culture, traditional customs and religious beliefs, which will hinder the improvement of resource acquisition ability and reduce the diversity of employment, resulting in the falling of some households into persistent poverty. Hence, the control variables at the village level include Townd ${ }_{i t}$ (distance from the village to the nearest market town),

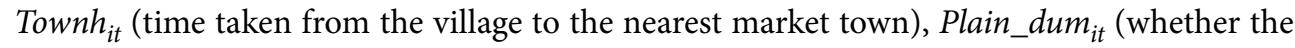

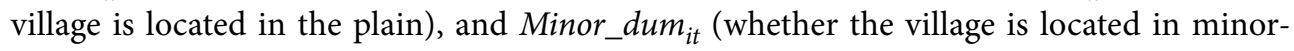
ity areas). Generally speaking, the plain area has advantages over other terrains in terms of farmer households' income and the provision of public goods (Gustafsson \& Wei, 2000; Luo et al., 2019).

\section{Data sources}

The core data of this paper were derived from the China Family Panel Studies (CFPS), which is a national representative large-scale micro-level household survey conducted by the China Social Sciences Research Center of Peking University. The survey is conducted every two years, and aims to reflect the changes in China's society, economy, population, as well as the education and health of the people by tracking and collecting data at the individual, family and community levels, to provide a data basis for academic research and public policy analysis. The survey sample of CFPS covers 14789 families from 635 villages/communities in 162 counties of 25 provinces in China, and the stratified multi-stage sampling design enables the sample to represent about $95 \%$ of China's population. Since CFPS provides large-scale hierarchical tracking data, we use the sample of households that are present in the survey of each year in 2012, 2014 and 2016, and obtain the corresponding data of these households at the village/community level. Therefore, the data used in this study are actually a micro data panel at the household level. In addition, in the instrumental variable regression, we also include the data of rainfall at the village level, which were derived from "China Meteorological Science Data Sharing Service Network". Table 1 and Table 2 present the variable interpretations and statistical descriptions in this study. 
Table 1. Definition of main variables

\begin{tabular}{|l|l|}
\hline Variable name & \\
\hline$\Delta \operatorname{Ln} c_{i j t}(\%)$ & Change rate of household consumption \\
\hline Expfl ${ }_{i j t}$ & $\begin{array}{l}\text { Fluctuationof household public expenditure measured by the amount of } \\
\text { government subsidies received by the household }\end{array}$ \\
\hline Income & Annual income of the household \\
\hline Familys & Total family size \\
\hline Asset & Sum of cash and deposits of the household \\
\hline health & $\begin{array}{l}\text { Health levels of family members (1-7 levels): the higher the value is, the better the } \\
\text { health status is }\end{array}$ \\
\hline Language & Daily language used in family: Putonghua $=1 ;$ dialect $=0$ \\
\hline Party & Whether the household head is a CCP member: Yes $=1 ;$ No $=0$ \\
\hline Age & Age of the household head \\
\hline Gender_dum & Gender of the household head: male $=1 ;$ female $=0$ \\
\hline Education & $\begin{array}{l}\text { Education years of the household head: illiteracy }=0 ; \text { primary school }=6 ; \text { junior } \\
\text { high school }=9 ; \text { senior high school and technical secondary school }=12 ; \text { junior } \\
\text { college }=15 ; \text { undergraduate }=16 ; \text { master }=19\end{array}$ \\
\hline Townd & Distance from the village to the nearest market \\
\hline Townh & Time taken from the village to the nearest market \\
\hline Plain_dum & Topography of the village: hilly area = 1; plain area = 0 \\
\hline Minor_dum & Whether the village is located in a minority area: Yes = 1; No = 0 \\
\hline disaster & Whether the village is a natural disaster prone area: Yes = 1; No =0 \\
\hline$\Delta$ Lnrainf $(m m)$ & Change rate of rainfall \\
\hline
\end{tabular}

Table 2. Statistical description

\begin{tabular}{|l|c|c|c|c|}
\hline \multicolumn{1}{|c|}{ Variable name } & Mean & SD & Max & Min \\
\hline$\Delta \mathrm{Lnc}$ & 57.865 & 184.921 & 1100.290 & -92.827 \\
\hline Expflc & 106.342 & 402.659 & 2900 & 0 \\
\hline Income & 49361.470 & 40388.940 & 151192 & 2901 \\
\hline Familys & 3.928 & 1.840 & 7 & 1 \\
\hline Asset & 25107.71 & 5688.13 & 300000 & 100 \\
\hline Health & 5.572 & 1.154 & 1 & 7 \\
\hline Party & 0.458 & 0.498 & 1 & 0 \\
\hline Language & 0.880 & 0.325 & 1 & 0 \\
\hline Age & 48.073 & 9.602 & 77 & 16 \\
\hline Gender_dum & 0.820 & 0.499 & 19 & 0 \\
\hline Education & 6.528 & 4.735 & 5162.654 & 77.541 \\
\hline Townd & 12.589 & 39.041 & 300 & 0 \\
\hline Townh & 1.446 & 5.009 & 45 & 0 \\
\hline Plain_dum & 0.450 & 0.497 & 1 & 0 \\
\hline Minor_dum & 0.084 & 0.277 & 1 & 0 \\
\hline disaster & 1.926 & 1.741 & 9 & -88.117 \\
\hline DLnrainf & 12.930 & 57.664 & 284.392 & \\
\hline
\end{tabular}




\section{Empirical results and interpretation}

\subsection{Panel unit root test}

It should be pointed out that because this paper uses large-scale panel data of farmers, a stochastic trend may occur due to the effect of random walk. Therefore, before the formal regression, it is necessary to test the unit root of the panel data of the explained variable and explanatory variable to avoid the spurious regression caused by data errors. Specifically, we used two kinds of tests: IPS (im-Pesaran-Shin) test and Fisher test. The reasons for choosing these two tests are as follows. First of all, we employed unbalanced panel data of farmers in three years, and these two tests are just for the short-term unbalanced panel data. Secondly, both tests can overcome the limitation of common root hypothesis. The common root hypothesis requires that the autoregressive coefficients of each individual are equal. However, in reality, the institutions and cultures vary greatly among different countries and regions, and even within a country. Obviously, this hypothesis is too strict in practice. Especially in this paper, we considered that the spatial environment has significant heterogeneity. Therefore, we believe that IPS test and Fisher test are suitable for the unit root test of the data in this paper. From the test results listed in Table 3, whether it will be IPS or Fisher tests, they all reject the null hypothesis of panel unit root.

Table 3. Panel unit root test results

\begin{tabular}{|c|c|c|c|}
\hline \multirow{3}{*}{ Variable } & \multicolumn{3}{|c|}{ Test method } \\
\cline { 2 - 4 } & & Statistic & P value \\
\hline \multirow{4}{*}{$\Delta \mathrm{Lnc}$} & IPS t-bar & -7.447 & 0.000 \\
\cline { 2 - 4 } & Fisher $\mathrm{p}$ & 967.668 & 0.000 \\
\cline { 2 - 4 } & Fisher $\mathrm{z}$ & -11.226 & 0.000 \\
\cline { 2 - 4 } & Fisher $\mathrm{L}^{*}$ & -19.278 & 0.000 \\
\cline { 2 - 4 } & Fisher pm & 30.554 & 0.000 \\
\hline \multirow{3}{*}{ Expflc } & IPS t-bar & -12.015 & 0.000 \\
\cline { 2 - 4 } & Fisher $\mathrm{p}$ & 776.559 & 0.000 \\
\cline { 2 - 4 } & Fisher $\mathrm{z}$ & -20.561 & 0.000 \\
\cline { 2 - 4 } & Fisher $\mathrm{L}^{*}$ & -16.331 & 0.000 \\
\cline { 2 - 4 } & Fisher pm & 26.287 & 0.000 \\
\cline { 2 - 4 } & & & \\
\hline
\end{tabular}

\subsection{Baseline regression}

Table 4 reports the estimation results of the baseline regression, in which Model 1 and Model 3 are OLS regression. When the characteristics at the household and village level are controlled, the fluctuation of rural public expenditure has a significant negative impact on the consumption growth rate of farm households. Besides, there may be some unobservable individual characteristics of the households and villages. For example, some inherent cultural characteristics of families or villages (such as some traditional customs of minority areas) do not change with public expenditure fluctuation, and because both the explained variables 
Table 4. Baseline estimate results

\begin{tabular}{|c|c|c|c|c|}
\hline$\Delta \operatorname{Ln} c_{i j t}$ & $\begin{array}{l}\text { Model } 1 \\
\text { OLS }\end{array}$ & $\begin{array}{c}\text { Model } 2 \\
\text { Two-way FE }\end{array}$ & $\begin{array}{l}\text { Model } 3 \\
\text { OLS }\end{array}$ & $\begin{array}{c}\text { Model } 4 \\
\text { Two-way FE }\end{array}$ \\
\hline $\operatorname{Expfl}_{i j t}$ & $\begin{array}{c}-0.000^{* *} \\
(0.000)\end{array}$ & $\begin{array}{c}-0.001^{* * *} \\
(0.000)\end{array}$ & $\begin{array}{c}-0.000^{* *} \\
(0.000)\end{array}$ & $\begin{array}{c}-0.001^{* * *} \\
(0.000)\end{array}$ \\
\hline \multicolumn{5}{|c|}{$X$} \\
\hline Income $_{i j t}$ & $\begin{array}{l}0.000^{* * *} \\
(0.000)\end{array}$ & $\begin{array}{l}0.000^{* * *} \\
(0.000)\end{array}$ & $\begin{array}{l}0.000^{* * *} \\
(0.000)\end{array}$ & $\begin{array}{l}0.000^{* * *} \\
(0.000)\end{array}$ \\
\hline Familys $_{i j t}$ & $\begin{array}{l}0.055^{* * *} \\
(0.012)\end{array}$ & $\begin{array}{l}0.121^{* * *} \\
(0.038)\end{array}$ & $\begin{array}{l}0.043^{* * *} \\
(0.013)\end{array}$ & $\begin{array}{l}0.106^{* * *} \\
(0.041)\end{array}$ \\
\hline Asset $_{i j t}$ & $\begin{array}{l}0.000^{* * *} \\
(0.000)\end{array}$ & $\begin{array}{l}0.000^{* * *} \\
(0.000)\end{array}$ & $\begin{array}{l}0.000^{* * *} \\
(0.000)\end{array}$ & $\begin{array}{l}0.000^{* * *} \\
(0.000)\end{array}$ \\
\hline Health $_{i j t}$ & $\begin{array}{c}0.055 \\
(0.017)\end{array}$ & $\begin{array}{c}0.046 \\
(0.031)\end{array}$ & $\begin{array}{c}0.031^{*} \\
(0.019)\end{array}$ & $\begin{array}{l}0.064^{*} \\
(0.034)\end{array}$ \\
\hline Language $_{i j t}$ & $\begin{array}{c}0.034 \\
(0.068)\end{array}$ & NA & $\begin{array}{c}0.071 \\
(0.072)\end{array}$ & NA \\
\hline Party $_{i j t}$ & $\begin{array}{c}0.041 \\
(0.040)\end{array}$ & $\begin{array}{l}-0.020 \\
(0.040)\end{array}$ & $\begin{array}{l}-0.000 \\
(0.044)\end{array}$ & $\begin{array}{l}-0.097 \\
(0.097)\end{array}$ \\
\hline$A g e_{i j t}$ & $\begin{array}{l}-0.024 \\
(0.019) \\
\end{array}$ & $\begin{array}{l}-0.158^{*} \\
(0.103) \\
\end{array}$ & $\begin{array}{l}-0.012 \\
(0.021)\end{array}$ & $\begin{array}{c}-0.079 \\
(0.11721)\end{array}$ \\
\hline$A g e^{2}{ }_{i j t}$ & $\begin{array}{c}0.000 \\
(0.000)\end{array}$ & $\begin{array}{c}0.001 \\
(0.001)\end{array}$ & $\begin{array}{c}0.000 \\
(0.000)\end{array}$ & $\begin{array}{c}0.001 \\
(0.001)\end{array}$ \\
\hline Gender_dum $_{i j t}$ & $\begin{array}{l}-0.018 \\
(0.039)\end{array}$ & NA & $\begin{array}{c}-0.0185 \\
(0.044)\end{array}$ & NA \\
\hline Education $_{i j t}$ & $\begin{array}{l}-0.002 \\
(0.005)\end{array}$ & $\begin{array}{c}-0.059^{* * *} \\
(0.023)\end{array}$ & $\begin{array}{l}-0.000 \\
(0.001)\end{array}$ & $\begin{array}{c}-0.056^{* *} \\
(0.025)\end{array}$ \\
\hline \multicolumn{5}{|c|}{$Z$} \\
\hline Townd $_{j t}$ & & & $\begin{array}{c}0.000 \\
(0.001)\end{array}$ & NA \\
\hline Townh $_{j t}$ & & & $\begin{array}{c}0.001 \\
(0.000)\end{array}$ & NA \\
\hline Plain_dum $m_{j t}$ & & & $\begin{array}{c}-0.153^{* * *} \\
(0.044)\end{array}$ & NA \\
\hline Minor_dum ${ }_{j t}$ & & & $\begin{array}{c}0.092 \\
(0.074)\end{array}$ & NA \\
\hline Heteroscedasticity & Yes & Yes & Yes & Yes \\
\hline Time fixed effects & No & Yes & No & Yes \\
\hline Individual fixed effects & No & Yes & No & Yes \\
\hline Hausman $\chi$ & & $8.841^{* * *}$ & & $8.434^{* * *}$ \\
\hline $\mathrm{R}^{2}$ & 0.332 & 0.148 & 0.360 & 0.215 \\
\hline Observations & 8918 & 8918 & 7267 & 7267 \\
\hline
\end{tabular}

Note: $(1){ }^{\star}$ Significantly different from zero at the 10 percent significance level, ${ }^{\star *} 5$ percent significance level, and ${ }^{* *} 1$ percent significance level; (2) SE in bracket; (3) NA means no result. 
and explanatory variables in this paper are growth rates, there may also be some missing variables that vary only with time. Therefore, Two-way FE estimation is adopted in Model 2 and Model 4, and the results also show that public expenditure fluctuation has a significant negative impact on the growth of household consumption. Finally, the Hausman test rejects the null hypothesis that there is no systematic difference between Fe estimation and $\mathrm{Re}$ estimation at the traditional significance level. As a whole, when the characteristics of the households and villages and the fixed effect are controlled, it can be preliminarily judged that the fluctuation of rural public expenditure is the cause of consumption loss, which leads to persistent poverty in rural areas.

\subsection{Instrumental variable regression}

Although in models 1-4, we have controlled as many factors as possible at the household and village level to reduce the possible errors of missing variables, in the "space environment" (such as incomplete credit market) where poor families live, some other unobservable factors may also have certain impacts on public expenditure and consumption, which will result in estimation errors. More importantly, there may be a reverse causal relationship between the

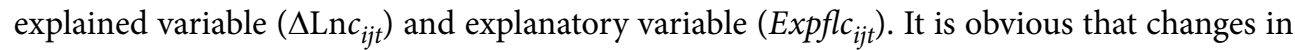
the consumption of farmer households (the change of poverty level) affect the implementation of poverty reduction policies, and thus exert certain influence on the investment of rural public expenditure. Hence, instrumental variable method was adopted to estimate the consumption growth model of farmer households. Specifically, the change in rainfall was used as the instrumental variable of rural public expenditure. Firstly, climate impact is a core factor affecting the agricultural output in China, and the government usually adjusts the scale of public expenditure in accordance with the impact of climate (Xu et al., 2011). In addition, current empirical research has also confirmed that the change in rainfall is a very effective instrumental variable for the economic fluctuation in developing countries (Brückner \& Gradstein, 2013, 2014; Luo et al., 2020). The estimation results of 2SLS are presented in Table 5.

Model 5 is the regression result with the control of only the characteristics of households. For every $1 \%$ fluctuation of rural public expenditure, the consumption of the farmer households will decrease by $0.88 \%$. When the characteristics at the village level are further controlled, the estimation results of Model 6 show that every 1\% fluctuation of rural public expenditure will lead to a $0.113 \%$ decrease in household consumption. The comparison shows that the estimation coefficient of Model 6 is higher than that of Model 5, possibly because the fluctuation of rural public expenditure has a more significant impact on consumption loss due to the real space environment of the farmer households. At the same time, the regression results of the first stage of 2SLS estimation are also reported in Table 5. It can be found that the fluctuation of rainfall has a significant positive correlation with the fluctuation of rural public expenditure, indicating that under relatively significant impacts of climate, the government will frequently adjust the public expenditure to cope with the adverse impact brought by climate changes on agricultural production, which is consistent with the conclusions of previous empirical studies (Luo et al., 2020). Finally, in the test of the validity of the instrumental variables, the F statistics of Durbin-Wu-Hausman's are greater 
Table 5. Estimation results of instrumental variables

\begin{tabular}{|c|c|c|}
\hline$\Delta \operatorname{Ln} c_{i j t}$ & $\begin{array}{c}\text { Model } 5 \\
\text { 2SLS (Second stage) }\end{array}$ & $\begin{array}{c}\text { Model } 6 \\
\text { 2SLS (Second stage) }\end{array}$ \\
\hline $\operatorname{Expfl}_{i j t}$ & $\begin{array}{l}-0.088^{* * *} \\
(0.012)\end{array}$ & $\begin{array}{c}-0.113^{\star * *} \\
(0.021)\end{array}$ \\
\hline $\begin{array}{l}\text { First stage: } \Delta \mathrm{Ln} \operatorname{Rain}_{j t} \text { for } \\
\Delta \mathrm{Ln} \operatorname{Exp}_{i j t}\end{array}$ & $\begin{array}{l}0.167^{* * *} \\
(0.022)\end{array}$ & $\begin{array}{l}0.399^{* * *} \\
(0.014)\end{array}$ \\
\hline \multicolumn{3}{|c|}{$X$} \\
\hline Income $_{i j t}$ & $\begin{array}{l}0.011^{\star * *} \\
(0.004)\end{array}$ & $\begin{array}{l}0.010^{* * *} \\
(0.004)\end{array}$ \\
\hline Familys $_{i j t}$ & $\begin{array}{l}0.050^{* * *} \\
(0.011)\end{array}$ & $\begin{array}{l}0.062^{* * *} \\
(0.015)\end{array}$ \\
\hline Asset $_{i j t}$ & $\begin{array}{l}0.001^{* * *} \\
(0.000)\end{array}$ & $\begin{array}{l}0.002^{* * *} \\
(0.000)\end{array}$ \\
\hline Health $_{i j t}$ & $\begin{array}{l}0.105^{* * *} \\
(0.033)\end{array}$ & $\begin{array}{l}0.234^{* * *} \\
(0.056)\end{array}$ \\
\hline Language $_{i j t}$ & $\begin{array}{l}0.000 \\
(0.000)\end{array}$ & $\begin{array}{l}0.000 \\
(0.000)\end{array}$ \\
\hline Party $_{i j t}$ & $\begin{array}{c}0.001 \\
(0.000)\end{array}$ & $\begin{array}{l}0.000 \\
(0.000)\end{array}$ \\
\hline$A g e_{i j t}$ & $\begin{array}{l}0.059^{* *} \\
(0.024)\end{array}$ & $\begin{array}{l}0.062^{* * *} \\
(0.021)\end{array}$ \\
\hline$A g e^{2}{ }_{i j t}$ & $\begin{array}{l}-0.013^{* * *} \\
(0.000)\end{array}$ & $\begin{array}{c}-0.047^{* * *} \\
(0.011)\end{array}$ \\
\hline Gender_dum ${ }_{i j t}$ & $\begin{array}{c}0.021 \\
(0.044)\end{array}$ & $\begin{array}{c}0.011 \\
(0.039) \\
\end{array}$ \\
\hline Education $_{i j t}$ & $\begin{array}{c}0.002 \\
(0.003)\end{array}$ & $\begin{array}{c}0.001 \\
(0.002)\end{array}$ \\
\hline \multicolumn{3}{|c|}{$Z$} \\
\hline Townd $_{j t}$ & & $\begin{array}{l}-0.001 \\
(0.003)\end{array}$ \\
\hline Townh $_{j t}$ & & $\begin{array}{l}-0.000 \\
(0.002)\end{array}$ \\
\hline Plain_dum ${ }_{j t}$ & & $\begin{array}{c}-0.278^{* * *} \\
(0.010)\end{array}$ \\
\hline Minor_dum ${ }_{j t}$ & & $\begin{array}{c}0.013 \\
(0.008)\end{array}$ \\
\hline Heteroscedasticity & Yes & Yes \\
\hline Durbin-Wu-Hausman $\chi$ & $10.587^{* * *}$ & $12.104^{* * *}$ \\
\hline Kleibergen-Paap rk LM & $42.763^{* * *}$ & $56.772^{* * *}$ \\
\hline Kleibergen-Paap rk Wald F & $365.250^{* * *}$ & $396.141^{* * *}$ \\
\hline $\mathrm{R}^{2}$ & 0.696 & 0.699 \\
\hline Observations & 8918 & 7627 \\
\hline
\end{tabular}

Note: $(1) *$ Significantly different from zero at the 10 percent significance level, ${ }^{* *} 5$ percent significance level, and ${ }^{* *} 1$ percent significance level; (2) SE in bracket. 
than 10, rejecting the null hypothesis that the variables are exogenous, and the statistics of Cragg-Donald Wald F test and Anderson canon. LM test are much higher than the critical value, proving the validity of the instrumental variables.

In addition, we also examined the impact of household characteristics on consumption changes. The regression results show that most household and individual characteristics have significant impacts on household consumption changes, and the direction of these impacts is also consistent with expectations. In general, household income, size and assets can play a smoothing role in consumption, so as to promote the growth of consumption. Besides, household consumption is also related to the health status of the family members: a better health status of the household will contribute to a faster growth of consumption. In terms of the characteristics of the household head, the influence of age on the growth of household consumption shows a shape of an inverted U. With increasing age of the household head, the growth rate of household consumption will become faster. However, when reaching a certain level, an increase in age is not conducive to the growth of household consumption, possibly because with the further increase of age, the household head is at a disadvantage in both health and knowledge, and tends to reduce household spending due to the risk aversion.

We also control the variables of village characteristics in the regression to capture the impact of space environment on consumption growth. The estimation results of Model 6 show that the dummy variable of terrain has a significant impact on the consumption growth of households. The farm households in hilly areas usually have relatively slower consumption growth. The distance and time from the village to the nearest market exhibit no significant impact on the consumption growth. A possible explanation is that although geographical location has an important impact on poverty, the impact is usually related to economic growth (Christiaensen \& Demery, 2007; Cunguara \& Darnhofer, 2011). In fact, if the space environment is taken into account, most poor areas have very low degrees of market development, and the farmer households have very limited participation in market activities. Thus, economic growth will have no significant effect on poverty reduction, which can also explain why the estimation coefficients of Townd ${ }_{j t}$ and Townh $h_{j t}$ are not significant in Model 6. In addition, the farmer households in ethnic areas do not exhibit a lower consumption growth.

Table 6. Exclusion restriction test of the instrumental variable

\begin{tabular}{|c|c|c|}
\hline$\Delta \operatorname{Ln} c_{i j t}$ & $\begin{array}{c}\text { Model } 7 \\
\text { OLS }\end{array}$ & $\begin{array}{c}\text { Model } 8 \\
\text { Two-way FE }\end{array}$ \\
\hline$\Delta \operatorname{Ln} \operatorname{Rain}_{j t}$ & $\begin{array}{l}-0.034 \\
(0.055)\end{array}$ & $\begin{array}{l}-0.021 \\
(0.016)\end{array}$ \\
\hline$X$ & Yes & Yes \\
\hline$Z$ & Yes & Yes \\
\hline Heteroscedasticity & Yes & Yes \\
\hline Time fixed effects & Yes & Yes \\
\hline Individual fixed effects & Yes & Yes \\
\hline Hausman $\chi$ & & $10.134^{* * *}$ \\
\hline $\mathrm{R}^{2}$ & 0.414 & 0.432 \\
\hline Observations & 7267 & 7267 \\
\hline
\end{tabular}

Note: The same as Table 4. 
The possible reasons may be related to the implementation of the "Rural Revitalization Plan" in China recently, which has vigorously developed characteristic industries in ethnic areas and increased the income of local farmer households.

Finally, it should be noted that although both of the regression results in the first stage and the relevant test of instrumental variables confirms the validity of the instrumental variables (Table 4), the variation of rainfall may not satisfy the "exclusion restriction" of instrumental variables. Therefore, we separately regressed the explained variable with the rainfall $\left(\Delta \operatorname{Ln} \operatorname{Rain}_{j t}\right)$, and the results in Table 6 are not statistically significant.

\subsection{Long-term impact}

In theory, when the farm households suffer from an uncertain shock, they will adjust intertemporal consumption to maximize the utility. Then, the fluctuation of rural public expenditure may have a long-term effect on the growth of households' consumption, that is, the current fluctuation of public expenditure affects not only the current consumption growth, but also the future consumption growth. In Table 7, Panel A is the regression results of the current consumption growth with the one-period lag fluctuation of rural public expenditure. Considering that the explanatory variable uses the lagged variable, there may be no endogenous problem. Therefore, only Two-way FE needs to be adopted to control the individual effect. According to the estimation results of Model 9 and Model 10, the one-period lag fluctuation of rural public expenditure has a significant negative impact on the current consumption growth. In the same way, Panel B is the regression results of the one-period ahead consumption growth with the current fluctuation of rural public expenditure. The results of Model 11 and Model 12 indicate that the current fluctuation of rural public expenditure will

Table 7. Estimation results of lag effect and expected effect

\begin{tabular}{|c|c|c|c|c|c|}
\hline \multicolumn{3}{|c|}{ Panel A: Lagging effect } & \multicolumn{3}{|c|}{ Panel B: Expectation effects } \\
\hline$\Delta \operatorname{Ln} c_{i j t}$ & $\begin{array}{c}\text { Model } 9 \\
\text { Two-way } \\
\text { FE }\end{array}$ & $\begin{array}{c}\text { Model } 10 \\
\text { Two-way } \\
\text { FE }\end{array}$ & $\Delta \operatorname{Ln} c_{i j, t+1}$ & $\begin{array}{c}\text { Model } 11 \\
\text { Two-way } \\
\text { FE }\end{array}$ & $\begin{array}{c}\text { Model } 12 \\
\text { Two-way } \\
\text { FE }\end{array}$ \\
\hline $\operatorname{Expfl}_{i j, t-1}$ & $\begin{array}{c}-0.001^{* *} \\
(0.000)\end{array}$ & $\begin{array}{l}-0.001^{*} \\
(0.000)\end{array}$ & $\operatorname{Expflc}_{i j t}$ & $\begin{array}{c}-0.009^{* *} \\
(0.004)\end{array}$ & $\begin{array}{c}-0.008^{* *} \\
(0.004)\end{array}$ \\
\hline$X$ & Yes & Yes & $X$ & Yes & Yes \\
\hline$Z$ & No & Yes & $Z$ & No & Yes \\
\hline Heteroscedasticity & Yes & Yes & Heteroscedasticity & Yes & Yes \\
\hline Time fixed effects & Yes & Yes & Time fixed effects & Yes & Yes \\
\hline $\begin{array}{l}\text { Individual fixed } \\
\text { effects }\end{array}$ & Yes & Yes & $\begin{array}{l}\text { Individual fixed } \\
\text { effects }\end{array}$ & Yes & Yes \\
\hline Hausman $\chi$ & $10.771^{* * *}$ & $14.311^{* * *}$ & Hausman $\chi$ & $12.878^{* * *}$ & $10.274^{* * *}$ \\
\hline $\mathrm{R}^{2}$ & 0.313 & 0.390 & $\mathrm{R}^{2}$ & 0.288 & 0.383 \\
\hline Observations & 5706 & 4873 & Observations & 6115 & 5118 \\
\hline
\end{tabular}

Note: The same as Table 4. 
also reduce the future consumption growth. Through examining the lag effect and expected effect, it can be suggested that the fluctuation of rural public expenditure is also the cause of long-term consumption loss, which further highlights the importance of public expenditure fluctuation in understanding rural persistent poverty.

\subsection{Spatial heterogeneity}

The estimation results in Table 5 demonstrate that topography is an important factor affecting consumption growth, but in previous regression, all the samples were put together without distinguishing the spatial heterogeneity of consumption growth of farm households. Therefore, to capture the impact of rural public expenditure fluctuation on consumption growth in different space environments in more detail, in this section, we first conducted regression of the topography in groups. In all regressions, the characteristics at the household and village level are controlled. The estimation results in Table 8 show that in Panel A, whether it be OLS, Two-way FE or 2SLS, the estimated elasticity coefficients are significantly negative, suggesting that in hilly-mountainous areas, the fluctuation of rural public expenditure inhibits the consumption growth of farm households; on the contrary, in Panel B, the estimated elastic coefficients of OLS, Two-way FE and 2SLS are not significant, demonstrating that in plain areas, the consumption behavior of farm households is not sensitive to the fluctuation of rural public expenditure.

Natural endowment is extremely important for agricultural production, and directly affects the income of farm households as well as helps to resist external shocks to some extent. In most of the hilly-mountainous areas, natural endowment is relatively poor. Taking cultivated land as an example, most cultivated land in hilly areas is highly fragmented slope cultivated land, which not only makes it difficult to realize mechanical substitution, but also hinders the transfer of cultivated land (Luo et al., 2019). This means that the farm households themselves and their social networks have rather limited ability to resist some uncertain external risk shocks, and can only rely on the government's public expenditure. In hilly-mountainous areas with poor space environment, there is usually a relatively higher frequency of external shocks, and an unstable scale of public expenditure will shorten the "time horizon" of the farm households, resulting in consumption loss. In particular, since the space environment cannot be improved in the short term, the impact of public expenditure fluctuation on consumption loss will be permanent, namely, persistent spatial poverty will occur.

Besides natural conditions (topography), spatial heterogeneity is also manifested as the agglomeration of poor people, which is an important feature of spatial poverty. Empirical research has revealed that the population with the lowest consumption growth rate tend to be clustered in space (Jalan \& Ravallion, 2002; De Vreyer et al., 2009). Thus, quantile regression can be adopted to capture this spatial heterogeneity. In Table 9, three quantiles, including $0.1,0.5$ and 0.9 , are used. The results indicate that with the increase of quantile, the quantile regression coefficient of rural public expenditure fluctuation is not significant at 0.5 and 0.9 , that is to say, the fluctuation of rural public expenditure has no effect on the consumption of farm households with higher income or lower spatial agglomeration, but the groups of farm households with the lowest income or highest spatial agglomeration have the most serious consumption loss. At the same time, the shape of Figure 2 also confirms the basic conclusion in Table 9. 
Table 8. Estimation results of terrain grouping

\begin{tabular}{|c|c|c|c|}
\hline$\Delta \operatorname{Ln} c_{i j t}$ & $\begin{array}{l}\text { Model } 13 \\
\text { OLS }\end{array}$ & $\begin{array}{c}\text { Model } 14 \\
\text { Two-way FE }\end{array}$ & $\begin{array}{c}\text { Model } 15 \\
\text { 2SLS (Second stage) }\end{array}$ \\
\hline \multicolumn{4}{|c|}{ Panel A: hilly-mountainous areas } \\
\hline $\operatorname{Expflc}_{i j t}$ & $\begin{array}{l}-0.000^{*} \\
(0.000)\end{array}$ & $\begin{array}{l}-0.001^{* * *} \\
(0.000)\end{array}$ & $\begin{array}{l}-0.121^{* * *} \\
(0.029)\end{array}$ \\
\hline $\bar{X}$ & Yes & Yes & Yes \\
\hline$Z$ & Yes & Yes & Yes \\
\hline Heteroscedasticity & Yes & Yes & Yes \\
\hline Time fixed effects & Yes & Yes & Yes \\
\hline Individual fixed effects & No & Yes & No \\
\hline Hausman $\chi$ & & $10.877^{* * *}$ & \\
\hline Durbin-Wu-Hausman $\chi$ & & & $14.530^{* * *}$ \\
\hline Kleibergen-Paap rk LM & & & $33.227^{* * *}$ \\
\hline $\begin{array}{l}\text { Kleibergen-Paap rk Wald } \\
\text { F }\end{array}$ & & & $277.605^{* * *}$ \\
\hline $\mathrm{R}^{2}$ & 0.325 & 0.317 & 0.614 \\
\hline Observations & 4030 & 4030 & 4030 \\
\hline \multicolumn{4}{|c|}{ Panel B: plain areas } \\
\hline $\operatorname{Expfl}_{i j t}$ & $\begin{array}{c}0.002 \\
(0.004)\end{array}$ & $\begin{array}{c}0.002 \\
(0.008)\end{array}$ & $\begin{array}{c}0.011 \\
(0.032)\end{array}$ \\
\hline$X$ & Yes & Yes & Yes \\
\hline$Z$ & Yes & Yes & Yes \\
\hline Heteroscedasticity & Yes & Yes & Yes \\
\hline Time fixed effects & Yes & Yes & Yes \\
\hline Individual fixed effects & No & Yes & No \\
\hline Hausman $\chi$ & & $14.505^{* * *}$ & \\
\hline Durbin-Wu-Hausman $\chi$ & & & $4.233^{*}$ \\
\hline Kleibergen-Paap rk LM & & & $28.575^{* * *}$ \\
\hline $\begin{array}{l}\text { Kleibergen-Paap rk Wald } \\
\text { F }\end{array}$ & & & $300.612^{* * *}$ \\
\hline $\mathrm{R}^{2}$ & 0.415 & 0.436 & 0.660 \\
\hline Observations & 3412 & 3412 & 3412 \\
\hline
\end{tabular}

Note: The same as Table 5. 

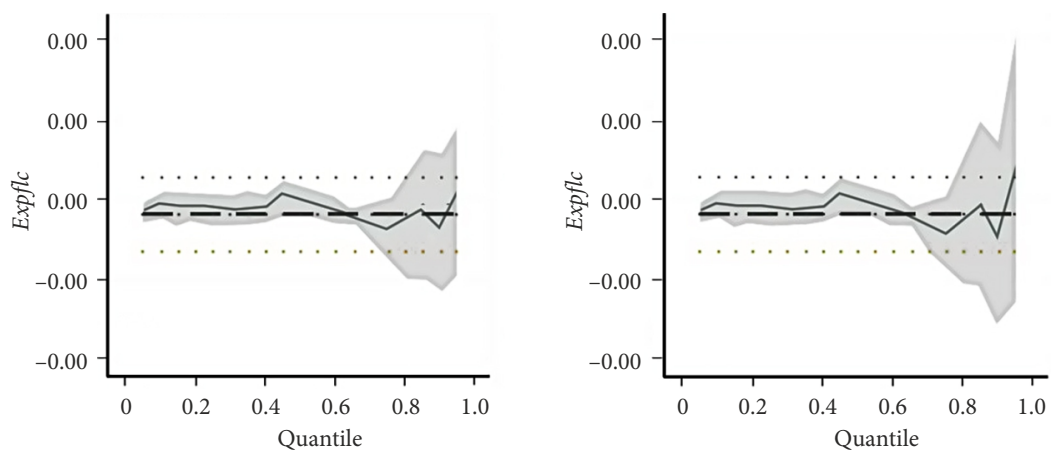

Figure 2. The change of quantile regression coefficient

Table 9. Estimation results of quantile regression

\begin{tabular}{|l|c|c|c|}
\hline \multirow{2}{*}{$\Delta \operatorname{Ln} c_{i j t}$} & \multicolumn{3}{|c|}{} \\
\cline { 2 - 4 } & $\begin{array}{c}\text { Model } 16 \\
\text { quantile } \mathrm{p}=0.1\end{array}$ & $\begin{array}{c}\text { Model 17 } \\
\text { quantile } \mathrm{p}=0.5\end{array}$ & $\begin{array}{c}\text { Model } 18 \\
\text { quantile } \mathrm{p}=0.9\end{array}$ \\
\hline \multirow{2}{*}{${\text { Expfl } c_{i j t}}^{*}$} & $-0.000^{* *}$ & -0.000 & 0.000 \\
$(0.000)$ & $(0.000)$ & Yes \\
\hline$X$ & Yes & Yes & Yes \\
\hline$Z$ & Yes & Yes & Yes \\
\hline Heteroscedasticity & Yes & Yes & 0.492 \\
\hline Pseudo R ${ }^{2}$ & 0.131 & 0.127 & 7267 \\
\hline Observations & 7267 & 7267 & \\
\hline
\end{tabular}

Note: $(1){ }^{\star}$ Significantly different from zero at the 10 percent significance level, ${ }^{\star *} 5$ percent significance level, and ${ }^{* *} 1$ percent significance level; (2) SE in bracket; (3) SE is set by bootstrap and sampling frequency is 200 .

\section{Robust test}

\subsection{Other forms of consumer spending}

In developing countries, health shock is one of the most common external shocks faced by households (Islam \& Maitra, 2012). As a temporary risk shock, health shock will only affect the household consumption under incomplete financial market in theory. If the market is complete, it is possible to smooth the consumption through risk sharing mechanism. At this time, consumption is only related to income level, and is not affected by temporary shocks such as health shock. In China's rural areas, on the one hand, the ability of the farm households to resist risks is weak; on the other hand, there is no formal financial market. Therefore, when the farm households suffer from health shock, they can only smooth the consumption through some external channels such as government assistance and social network (Liu, 2016). As mentioned above, in areas with adverse space environments, the role of social capital is greatly weakened. Once the government expenditure is unstable, the farm households will reduce their health expenditure, which is not conducive to the accumula- 
tion of human capital, resulting in a high probability of falling into poverty trap. At the same time, according to Engel's law, the increase in the expenditure on culture and education can also reflect the poverty reduction of the households to some extent. Therefore, the growth rate of family health expenditure $\Delta \mathrm{Ln} M e d_{i j t}$ and that of culture and education expenditure $\Delta \mathrm{LnCu} l_{i j t}$ are used to replace the original explained variable to carry out the robust test. The results are reported in Table 10.

From the estimation results in Table 10, when OLS, two-way Fe and 2SLS are used,

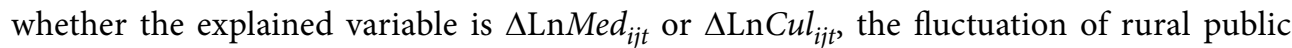
expenditure always shows a significant negative impact on the growth rate of consumption. Specifically, for every $1 \%$ fluctuation of rural public expenditure, there will be a $0.074 \%$ decrease in family health expenditure and a $0.177 \%$ decrease in family culture and education

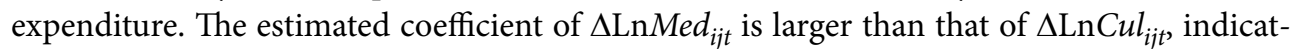
ing that when the farm households are faced with an unstable expectation, the priority is to protect the health of family members. However, the relative lack of investment in culture and education in the long term will reduce the probability of the households to get out of poverty trap.

Table 10. Estimated results of other forms of consumption spending

\begin{tabular}{|l|c|c|c|c|c|c|}
\hline \multirow{2}{*}{ Explained variables } & \multicolumn{3}{|c|}{$\Delta$ LnMed $_{i j t}$} & \multicolumn{3}{c|}{$\Delta$ LnCul $_{i j t}$} \\
\cline { 2 - 7 } & $\begin{array}{c}\text { Model 19 } \\
\text { OLS }\end{array}$ & $\begin{array}{c}\text { Model 20 } \\
\text { Two-way } \\
\text { FE }\end{array}$ & $\begin{array}{c}\text { Model 21 } \\
\text { 2SLS }\end{array}$ & $\begin{array}{c}\text { Model 22 } \\
\text { OLS }\end{array}$ & $\begin{array}{c}\text { Model 23 } \\
\text { Two-way } \\
\text { FE }\end{array}$ & $\begin{array}{c}\text { Model 24 } \\
\text { 2SLS }\end{array}$ \\
\hline Expflc $_{i j t}$ & $\begin{array}{c}-0.001^{* * *} \\
(0.000)\end{array}$ & $\begin{array}{c}-0.001^{* * *} \\
(0.000)\end{array}$ & $\begin{array}{c}-0.074^{* * *} \\
(0.022)\end{array}$ & $\begin{array}{c}-0.002^{* * *} \\
(0.000)\end{array}$ & $\begin{array}{c}-0.001^{* *} \\
(0.000)\end{array}$ & $\begin{array}{c}-0.177^{* * *} \\
(0.025)\end{array}$ \\
\hline$X$ & Yes & Yes & Yes & Yes & Yes & Yes \\
\hline$Z$ & Yes & Yes & Yes & Yes & Yes & Yes \\
\hline Heteroscedasticity & Yes & Yes & Yes & Yes & Yes & Yes \\
\hline Hausman $\chi$ & & $10.877^{* * *}$ & & & $19.764^{* * *}$ & \\
\hline Durbin-Wu-Hausman $\chi$ & & & $5.844^{*}$ & & & $16.814^{*}$ \\
\hline Kleibergen-Paap rk LM & & & $30.732^{* * *}$ & & & $46.787^{* * *}$ \\
\hline $\begin{array}{l}\text { Kleibergen-Paap rk } \\
\text { Wald F }\end{array}$ & & & $132.707^{* * *}$ & & & $205.660^{* * *}$ \\
\hline $\mathrm{R}^{2}$ & 0.094 & 0.061 & 0.565 & 0.054 & 0.151 & 0.601 \\
\hline Observations & 7669 & 7490 & 7669 & 3490 & 3415 & 3490 \\
\hline
\end{tabular}

Note: The same as Table 4.

\subsection{Group regression considering the degree of disaster}

In section 4.4, we have examined two kinds of spatial heterogeneity: topography difference and agglomeration degree difference. In fact, disaster degree is also an extremely important indicator to reflect the advantages and disadvantages of the space environment. In CFPS data, natural disasters mainly include nine categories: (1) drought; (2) flood; (3) forest fire; (4) frost damage, hail disaster; (5) typhoon, storm surge; (6) landslide, rock-mud flow; (7) agricultural and forestry pests; (8) earthquake; and (9) infectious diseases. We believe 
that if the village/community where the households live suffers from two or more different natural disasters within one year, it can be regarded as an area of frequent natural disasters; if not, it is considered as a normal area. Table 11 reports the regression results grouped by the degree of disaster. It can be found that the fluctuation of rural public expenditure only has significant negative impacts on consumption growth in areas with frequent natural disasters. The regression results in Table 11 are consistent with the main conclusions on spatial heterogeneity in section 4.4, namely, in a worse space environment, the fluctuation of rural public expenditure will cause more serious consumption loss.

Table 11. The estimation results of group regression of disaster degree

\begin{tabular}{|c|c|c|c|}
\hline$\Delta \operatorname{Ln} c_{i j t}$ & $\begin{array}{l}\text { Model } 25 \\
\text { OLS }\end{array}$ & $\begin{array}{c}\text { Model } 26 \\
\text { Two-way FE }\end{array}$ & $\begin{array}{c}\text { Model 27 } \\
\text { 2SLS (Second stage) }\end{array}$ \\
\hline \multicolumn{4}{|c|}{ Panel A: Areas with frequent natural disasters } \\
\hline $\operatorname{Expfl}_{i j t}$ & $\begin{array}{l}-0.000 \\
(0.000)\end{array}$ & $\begin{array}{l}-0.001^{* * *} \\
(0.000)\end{array}$ & $\begin{array}{l}-0.277^{* * \star} \\
(0.111)\end{array}$ \\
\hline$X$ & Yes & Yes & Yes \\
\hline$Z$ & Yes & Yes & Yes \\
\hline Heteroscedasticity & Yes & Yes & Yes \\
\hline Time fixed effects & Yes & Yes & Yes \\
\hline Individual fixed effects & No & Yes & No \\
\hline Hausman $\chi$ & & $10.877^{* * *}$ & \\
\hline Durbin-Wu-Hausman $\chi$ & & & $11.144^{* * *}$ \\
\hline Kleibergen-Paap rk LM & & & $28.255^{* *}$ \\
\hline $\begin{array}{l}\text { Kleibergen-Paap rk Wald } \\
\text { F }\end{array}$ & & & $251.005^{* * *}$ \\
\hline $\mathrm{R}^{2}$ & 0.271 & 0.210 & 0.602 \\
\hline Observations & 3957 & 3876 & 3957 \\
\hline \multicolumn{4}{|c|}{ Panel B: General areas } \\
\hline $\operatorname{Expfl}_{i j t}$ & $\begin{array}{l}-0.001 \\
(0.002)\end{array}$ & $\begin{array}{l}-0.002 \\
(0.005) \\
\end{array}$ & $\begin{array}{c}-0.014 \\
(0.0552) \\
\end{array}$ \\
\hline$X$ & Yes & Yes & Yes \\
\hline$Z$ & Yes & Yes & Yes \\
\hline Heteroscedasticity & Yes & Yes & Yes \\
\hline Time fixed effects & Yes & Yes & Yes \\
\hline Individual fixed effects & No & Yes & No \\
\hline Hausman $\chi$ & & $9.770^{* * *}$ & \\
\hline Durbin-Wu-Hausman $\chi$ & & & $13.230^{* * *}$ \\
\hline Kleibergen-Paap rk LM & & & $37.646^{* * *}$ \\
\hline $\begin{array}{l}\text { Kleibergen-Paap rk Wald } \\
\text { F }\end{array}$ & & & $288.654^{* * *}$ \\
\hline $\mathrm{R}^{2}$ & 0.397 & 0.561 & 0.661 \\
\hline Observations & 3690 & 3563 & 3690 \\
\hline
\end{tabular}

Note: The same as Table 4. 


\section{Conclusions and suggestions}

By using the data of households and villages in China Family Panel Studies (CFPS) in 2012, 2014 and 2016, and the climate data of "China Meteorological Science Data Sharing Service Network", this study investigates the impact of rural public expenditure fluctuation on the consumption loss of farm households. With the estimation method of instrumental variables, the regression results show that the fluctuation of public expenditure hinders the consumption growth of farm households. Specifically, every $1 \%$ fluctuation of rural public expenditure will lead to a $0.113 \%$ decrease in the consumption of farm households. In addition, it was found that the fluctuation of rural public expenditure is the cause of long-term consumption loss. Finally, the spatial heterogeneity test proves that in worse space environment (topography, agglomeration, disaster), rural public expenditure fluctuation has a more obvious inhibitory effect on the consumption growth of farm households.

An ongoing debate in developing countries is whether poverty reduction should depend on economic growth or large-scale government intervention. Earlier literature was mainly focused on economic growth, and some new research has started to examine rural poverty from the perspective of spatial externality, providing new insights into the causes and interventions of poverty. However, the current empirical research on spatial poverty fails to satisfactorily illustrate how spatial factors lead to poverty traps. This paper attempts to explain that in the area with adverse space environment, the effect of economic growth and social capital on poverty reduction will be weakened. The major means of fighting against rural poverty mainly is the administrative assistance from the government. Once the scale of rural public expenditure is unstable, the expectation of households will be "deteriorated", resulting in the reduction of household consumption and falling into poverty trap. In the majority of developing countries, the local governments bear most of the fiscal responsibility for poverty reduction, and at the same time the rural public expenditure is pro-cyclical (Luo et al., 2020), which means that the poorer areas are less capable of implementing counter cyclical policies, so in the long term, poverty governance will have very limited effect. Therefore, externality (geography, nature) itself does not necessarily lead to spatial poverty; instead, it may be the public expenditure fluctuation associated with externality that causes spatial poverty, which is not concerned by previous research and is the main contribution of this paper.

Based on this research, some policy recommendations can be made for the reduction of spatial poverty in rural China. First of all, a stable scale of rural public expenditure should be provided. The feasible way is to establish a subsidy system of central finance for agricultural insurance business management and agricultural reinsurance, and decisions on the proportion and amount of subsidy should attach equal importance to policy needs and regional differences to achieve differentiated management of subsidies for operation and management. Secondly, the structure and direction of rural public expenditure should be adjusted. In terms of the structure, the share of rural public expenditure should be increased in the central finance budget. Particularly in the time of economic depression, the transfer payment to underdeveloped areas should be enhanced to assist the local governments to implement counter cyclical public policies; in terms of direction, future policies should be directed to transform local finance into public finance, so as to reduce the direct investment of local finance in industry and increase the investment in the local space environment (infrastructure and education). 


\section{Funding}

National Natural Science Foundation of China (71974071; 71974070; 42171286).

\section{References}

Alkire, S., Roche, J. M., Seth, S., \& Sumner, A. (2015). Identifying the poorest people and groups: Strategies using the Global Multidimensional Poverty Index. Journal of International Development, 27(3), 362-387. https://doi.org/10.1002/jid.3083

Angelucci, M., Giorgi, G. D., Rangel, M. A., \& Rasul, I. (2009). Family networks and school enrolment: Evidence from a randomized social experiment. Journal of Public Economics, 94(3).

https://doi.org/10.3386/w14949

Barbier, E. B., \& Hochard, J. P. (2019). Poverty-environment traps. Environmental and Resource Economics, 74(3), 1239-1271. https://doi.org/10.1007/s10640-019-00366-3

Bebbington, A. (1999). Capitals and capabilities: a framework for analyzing peasant viability, rural livelihoods and poverty. World Development, 27(12), 2021-2044.

https://doi.org/10.1016/S0305-750X(99)00104-7

Besley, T., \& Burgess, R. (2003). Halving global poverty. Journal of Economic Perspectives, 17(3), 3-22. https://doi.org/10.1257/089533003769204335

Bird, K., \& Shepherd, A. (2003). Livelihoods and chronic poverty in semi-arid Zimbabwe. World Development, 31(3), 591-610. https://doi.org/10.1016/S0305-750X(02)00220-6

Bloom, D. E., Canning, D., \& Sevilla, J. (2003). Geography and poverty traps. Journal of Economic Growth, 8(4), 355-378. https://doi.org/10.1023/A:1026294316581

Brückner, M., \& Gradstein, M. (2013). Exogenous volatility and the size of government in developing countries. Journal of Development Economics, 105, 254-266. https://doi.org/10.1016/j.jdeveco.2013.08.005

Brückner, M., \& Gradstein, M. (2014). Government spending cyclicality: Evidence from transitory and persistent shocks in developing countries. Journal of Development Economics, 111, 107-116. https://doi.org/10.1016/j.jdeveco.2014.08.003

Chiswick, B. R., \& Miller, P. W. (1995). The endogeneity between language, earnings: International analyses. Journal of Labor Economics, 13(2), 246-288. https://doi.org/10.1086/298374

Chou, S. Y., Liu, J. T., \& Huang, C. J. (2004). Health insurance and savings over the life cycle-a semiparametric smooth coefficient estimation. Journal of Applied Econometrics, 19(3), 295-322. https://doi.org/10.1002/jae.735

Christiaensen, L., \& Demery, L. (2007). Down to earth: Agriculture and poverty reduction in Africa. The World Bank, Washington D.C. https://doi.org/10.1596/978-0-8213-6854-1

Combes, J., Renard, M., \& Tapsoba, S. J. A. (2019). Provincial public expenditure in China: A tale of pro-cyclicality. Economic Change and Restructuring, 52(1), 19-41. https://doi.org/10.1007/s10644-017-9215-4

Cunguara, B., \& Darnhofer, I. (2011). Assessing the impact of improved agricultural technologies on household income in rural Mozambique. Food Policy, 36(3), 378-390. https://doi.org/10.1016/j.foodpol.2011.03.002

Daimon, T. (2001). The spatial dimension of welfare and poverty: Lessons from a regional targeting programme in Indonesia. Asian Economic Journal, 15(4), 345-367.

https://doi.org/10.1111/1467-8381.00149 
Dao, N. T., \& Edenhofer, O. (2018). On the fiscal strategies of escaping poverty-environment traps towards sustainable growth. Journal of Macroeconomics, 55, 253-273.

https://doi.org/10.1016/j.jmacro.2017.10.007

De Vreyer, P., Herrera, J., \& Mesplé-Somps, S. (2009). Consumption growth and spatial poverty traps: an analysis of the effect of social services and community infrastructures on living standards in rural Peru. In Poverty, inequality, and policy in Latin America (pp. 129-155). MIT Press.

Dercon, S., \& Christiaensen, L. (2011). Consumption risk, technology adoption and poverty traps: Evidence from Ethiopia. Journal of Development Economics, 96(2), 159-173. https://doi.org/10.1016/j.jdeveco.2010.08.003

Dercon, S. (2002). Income risk, coping strategies and safety nets. World Bank Research Observer, 17(2), 141-166. https://doi.org/10.1093/wbro/17.2.141

Dinkelman, T., \& Schulhofer-Wohl, S. (2015). Migration, congestion externalities, and the evaluation of spatial investments. Journal of Development Economics, 114, 189-202. https://doi.org/10.1016/j.jdeveco.2014.12.009

Dollar, D., \& Kraay, A. (2002). Growth is good for the poor. Journal of Economic Growth, 7(3), 195-225. https://doi.org/10.1023/A:1020139631000

Dong, Y., Jin, G., Deng, X. Z., \& Wu, F. (2021). Multidimensional measurement of poverty and its spatiotemporal dynamics in China from the perspective of development geography. Journal of Geographical Sciences, 31(1), 130-148. https://doi.org/10.1007/s11442-021-1836-x

Epprecht, M., Müller, D., \& Minot, N. (2011). How remote are Vietnam's ethnic minorities? An analysis of spatial patterns of poverty and inequality. The Annals of Regional Science, 46(2), 349-368. https://doi.org/10.1007/s00168-009-0330-7

Eswaran, M., \& Kotwal, A. (1990). Implications of credit constraints for risk behaviour in less developed economies. Oxford Economic Papers, 42(2), 473-482. https://doi.org/10.1093/oxfordjournals.oep.a041958

Glauben, T., Herzfeld, T., Rozelle, S., \& Wang, X. (2012). Persistent poverty in rural China: Where, why, and how to escape? World Development, 40(4), 784-795.

https://doi.org/10.1016/j.worlddev.2011.09.023

Guo, B., He, D., Zhao, X., Zhang, Z., \& Dong, Y. (2020). Analysis on the spatiotemporal patterns and driving mechanisms of China's agricultural production efficiency from 2000 to 2015. Physics and Chemistry of the Earth, 120, 102909. https://doi.org/10.1016/j.pce.2020.102909

Gustafsson, B., \& Wei, Z. (2000). How and why has poverty in china changed? A study based on microdata for 1988 and 1995. China Quarterly, 144(4), 983-1006. https://doi.org/10.1017/S0305741000019263

Hidalgo-Hidalgo, M., \& Iturbe-Ormaetxe, I. (2018). Long-run effects of public expenditure on poverty. The Journal of Economic Inequality, 16(1), 1-22. https://doi.org/10.1007/s10888-017-9360-Z

Islam, A., \& Maitra, P. (2012). Health shocks and consumption smoothing in rural households: Does micro credit have a role to play? Journal of Development Economics, 97(2), 232-243. https://doi.org/10.1016/j.jdeveco.2011.05.003

Jalan, J., \& Ravallion, M. (1999). Are the poor less well insured? Evidence on vulnerability to income risk in rural China. Journal of Development Economics, 58(1), 61-81. https://doi.org/10.1016/S0304-3878(98)00103-5

Jalan, J., \& Ravallion, M. (2002). Geographic poverty traps? A micro model of consumption growth in rural China. Journal of Applied Econometrics, 17(4), 329-346. https://doi.org/10.1002/jae.645

Jin, G., Deng, X., Zhao, X., Guo, B., \& Yang, J. (2018). Spatiotemporal patterns in urbanization efficiency within the Yangtze River Economic Belt between 2005 and 2014. Journal of Geographical Sciences, 28(8), 1113-1126. https://doi.org/10.1007/s11442-018-1545-2 
Jin, G., Shi, X., He, D., Guo, B., Li, Z., \& Shi, X. (2020a). Designing a spatial pattern to rebalance the orientation of development and protection in Wuhan. Journal of Geographical Sciences, 30(4), 569-582. https://doi.org/10.1007/s11442-020-1743-6

Jin, G., Guo, B. S., \& Deng, X. Z. (2020b). Is there a decoupling relationship between $\mathrm{CO}_{2}$ emission reduction and poverty alleviation in China? Technological Forecasting \& Social Change, 151, 119856. https://doi.org/10.1016/j.techfore.2019.119856

Knight, J., \& Yueh, L. (2008). The role of social capital in the labour market in China. Economics of Transition, 16(3), 389-414. https://doi.org/10.1111/j.1468-0351.2008.00329.x

Kraay, A. (2006). When is growth pro-poor? Evidence from a panel of countries. Journal of Development Economics, 80(1), 198-227. https://doi.org/10.1016/j.jdeveco.2005.02.004

Laajaj, R. (2017). Endogenous time horizon and behavioral poverty trap: Theory and evidence from Mozambique. Journal of Development Economics, 127, 187-208. https://doi.org/10.1016/j.jdeveco.2017.01.006

Liu, K. (2016). Insuring against health shocks: health insurance and household choices. Journal of Health Economics, 46, 16-32. https://doi.org/10.1016/j.jhealeco.2016.01.002

Liu, Y., Liu, J., \& Zhou, Y. (2017). Spatio-temporal patterns of rural poverty in China and targeted poverty alleviation strategies. Journal of Rural Studies, 52, 66-75. https://doi.org/10.1016/j.jrurstud.2017.04.002

Luo, X., Zhang, Z., Lu, X., \& Zhang, L. (2019). Topographic heterogeneity, rural labor transfer and cultivated land use: An empirical study of plain and low-hill areas in China. Papers in Regional Science, 8(5), 2157-2178. https://doi.org/10.1111/pirs.12444

Luo, X., Lu, X., Zhang, Z., \& Pan, Y. (2020). Regional differences and rural public expenditure cyclicality: evidence from transitory and persistent shocks in China. The Annals of Regional Science, 65, 281-318. https://doi.org/10.1007/s00168-020-00985-5

Munshi, K., \& Rosenzweig, M. (2009). Why is mobility in India so low? Social insurance, inequality, and growth (Working Paper No. 14850). National Bureau of Economic Research. https://doi.org/10.3386/w14850

Narayan, D., Patel, R., Schafft, K., Rademacher, A., \& Koch-Schulte, S. (2000). Voices of the poor: Can anyone hear us? Oxford University Press. https://doi.org/10.1596/0-1952-1601-6

Ohno, H. (2015). Limited market participation, financial intermediation, and consumption smoothing. International Journal of Economics and Finance, 7(3), 36-44. https://doi.org/10.5539/ijef.v7n3p36

Ravallion, M. (2001). Growth, inequality and poverty: Looking beyond averages. World Development, 29(11), 1803-1815. https://doi.org/10.1016/S0305-750X(01)00072-9

Ravallion, M., \& Wodon, Q. (1999). Poor areas, or only poor people? Journal of Regional Science, 39(4), 689-711. https://doi.org/10.1111/0022-4146.00156

Rosenzweig, M., \& Binswanger, H. (1993). Wealth, weather risk and the composition and profitability of agricultural investments. Economic Journal, 103(416), 56-78. https://doi.org/10.2307/2234337

Rozelle, S., Zhang, L. X., \& Huang, J. K. (2000). China's war on poverty (Working Paper No. 60). Center for Economic Research on Economic Development and Policy Reform, Stanford Institute for Economic Policy Research, Stanford University.

Segal, B., \& Podoshen, J. S. (2013). An examination of materialism, conspicuous consumption and gender differences. International Journal of Consumer Studies, 37(2), 189-198.

https://doi.org/10.1111/j.1470-6431.2012.01099.x

Sen, A. (1999). Development as freedom. Oxford University Press.

Schultz, T. P. (2004). School subsidies for the poor: evaluating the Mexican Progresa poverty program. Journal of Development Economics, 74(1), 199-250. https://doi.org/10.1016/j.jdeveco.2003.12.009 
Shim, E. Y. (2014). The impact of conditional cash transfer programs under risk-sharing arrangements: Schooling and consumption smoothing in rural Mexico. University of Pennsylvania.

Shujaat, F., \& Usman, A. (2020). Economic growth and rural poverty in Pakistan: A panel dataset analysis. The European Journal of Development Research, 32(4), 1128-1150. https://doi.org/10.1057/s41287-020-00259-y

World Bank. (1981). World Development Report 1981/1982. Oxford University Press.

World Bank. (2000a). Geographical targeting for poverty alleviation: Methodology and applications (D. Bigman, \& H. Fofack, Eds.). Washington, D. C.

World Bank. (2000b). World Development Report 2000/2001. Oxford University Press.

Xu, L., Zhang, Q., \& Zhang, X. (2011). Evaluating agricultural catastrophic risk. China Agricultural Economic Review, 3(4), 451-461. https://doi.org/10.1108/17561371111192310

Zhou, L., \& Xiong, L.-Y. (2017). Natural topographic controls on the spatial distribution of povertystricken counties in China. Applied Geography, 90, 282-292. https://doi.org/10.1016/j.apgeog.2017.10.006

Zimmerman, F. J., \& Carter, M. R. (2003). Asset smoothing, consumption smoothing, and the reproduction of inequality under risk and subsistence constraints. Journal of Development Economics, 7(2), 233-260. https://doi.org/10.1016/S0304-3878(03)00028-2

Zou, W., \& Liu, Y. (2010). Skilled labor, economic transition and income differences: A dynamic approach. Annals of Economics and Finance, 11(2), 247-275. 